\title{
INTRODUKSI TEKNOLOGI PEMBUATAN WALL DECORATION MELALUI PELATIHAN WIRAUSAHA MANDIRI DI KOTA METRO
}

\author{
Nurul Farida*), Lilian Mega Puri, dan Triani Ratnawuri \\ Fakultas Keguruan dan Ilmu Pendidikan Universitas Muhammadiyah Metro \\ *)Email: nurulfaridamath@gmail.com
}

\begin{abstract}
ABSTRAK
Tujuan kegiatan adalah untuk memberikan pelatihan pembuatan wall decoration kain flanel sebagai bekal wirausaha mandiri remaja panti asuhan Tuma'ninah Yasin. Dengan tampilan yang warnawarni membuat kain flanel lebih menarik untuk dibuat kreasi produk kerajinan yang bernilai jual. Kelebihan lain dari kain flanel adalah harganya yang terjangkau sehingga memungkinkan berwirausaha dengan modal yang tidak terlalu besar. Melalui pelatihan pembuatan wall decoration kain flanel ini diharapkan dapat menjadi bekal wira usaha mandiri bagi remaja panti asuhan Tuma'ninah Yasin Kota Metro. Mitra kegiatan ini adalah remaja panti asuhan Tuma'ninah Yasin Kota Metro. Kelompok remaja panti asuhan Tuma'ninah Yasin Kota Metro sebagai mitra yang mayoritas beranggotakan anak-anak remaja yang aktif dan produktif. Panti asuhan Tuma'ninah Yasin memiliki banyak remaja putra dan putri yang aktif dan produktif, namun mereka belum memiliki kemampuan dan keterampilan menghasilkan produk layak jual. Tempat pelaksanaan kegiatan pelatihan adalah di masjid Panti Asuhan Tuma'ninah Yasin Kota Metro. Metode yang digunakan dalam kegiatan ini adalah metode demonstrasi, tanya jawab, diskusi, dan praktek. Hasil kegiatan yang diperoleh yaitu peserta pelatihan/mitra dapat mengembangkan pembuatan berbagai macam kerajinan/produk handmade dari kain flanel sehingga mampu mengembangkan dan menjadi bekal wirausaha mandiri. Berdasarkan hasil kegiatan dapat ditarik kesimpulan bahwa $93 \%$ peserta pelatihan memiliki pengetahuan dan keterampilan dalam pembuatan wall decoration kain flanel.
\end{abstract}

Kata Kunci: flanel, hiasan dinding, wirausaha

\section{Wall Decoration Making Technology Introduction through Mandiri Entrepreneurship Training in Metro City}

\begin{abstract}
The activity aimed to provide training in making flannel wall decoration as a provision for independent entrepreneurship for Tuma'ninah Yasin youth orphanage. It makes flannel more attractive with a colorful appearance to make craft products that have a sale value. Another advantage of flannel is that it is affordable, making it possible to do entrepreneurship with small capital. Through this training on making flannel wall decoration, it is hoped that it can become a provision for teenagers' independent entrepreneurship at the Tuma'ninah Yasin orphanage, Metro City. The partners of this activity are teenagers at the Tuma'ninah Yasin orphanage, Metro City. The group of teenagers at the Tuma'ninah Yasin orphanage, Kota Metro, is a partner with the most active and productive teenagers. The Tuma'ninah Yasin orphanage has many young men and women who are active and productive, but they do not have the ability and skills to produce products that are worth selling. The venue for the training activities is at the Tuma'ninah Yasin Orphanage Mosque, Metro City. The methods used in this activity are demonstration, question and answer, discussion, and practice methods. The results of the activities obtained are that the training participants/partners can develop the manufacture of various kinds of handicrafts / handmade products from flannel to develop and become provisions for independent entrepreneurs. Based on the activity results, it can be concluded that $93 \%$ of the training participants have the knowledge and skills in making flannel wall decorations.
\end{abstract}

Keywords: flannel, wall decoration, entrepreneurship 


\section{PENDAHULUAN}

Kelompok remaja panti asuhan Tuma'ninah Yasin Kota Metro sebagai mitra yang mayoritas beranggotakan anak-anak remaja yang aktif dan produktif. Panti asuhan Tuma'ninah Yasin memiliki banyak remaja putra dan putri yang aktif dan produktif, namun mereka belum memiliki kemampuan dan keterampilan menghasilkan produk layak jual. Berdasarkan hasil wawancara dengan pengurus panti yaitu Ibu Nani Kusrini bahwa sebelumnya telah ada produk hasil kerajinan tangan berupa manik-manik. Namun belum pernah ada kegiatan pelatihan kerajinan dari kain flanel. Oleh karena itu perlu dibekali kemampuan berwirausaha sebagai bekal hidup mandiri. Sebagaimana yang diungkapkan oleh Wibowo (2011) bahwa kewirausahaan merupakan semangat, sikap, perilaku kemampuan seseorang dalam menangani usaha dan atau kegiatan yang mengarah pada upaya mencari, menciptakan, menerapkan cara kerja, teknologi dan produk baru dengan meningkatkan efisiensi dalam rangka memberikan pelayanan yang lebih baik dan atau memperoleh keuntungan yang lebih besar, yang tidak hanya dapat dilakukan oleh pengusaha tapi juga dapat dilakukan oleh setiap orang baik tua ataupun muda. Wirausaha berarti mengarah kepada tenaga dan pikiran untuk mencapai suatu maksud (Firdani, dkk, 2017). Lebih lanjut Sukirman (2017) menyatakan bahwa jiwa kewirausahaan mempunyai pengaruh secara langsung terhadap perilaku kewirausahaan dan pengaruh tidak langsung terhadap kemandirian usaha. Salah satu upaya untuk menumbuhkan jiwa kewirausahaan adalah melalui kegiatan pelatihan.

Pelatihan adalah proses di mana seseorang mencapai kemampuan tertentu untuk membantu mencapai tujuan organisasi yang cenderung berorientasi jangka pendek (Sulaefi, 2017). Pelatihan juga merupakan salah satu faktor yang memengaruhi kinerja seseorang (Hendarawan dan Wahyuni, 2016; Sulaefi, 2017). Sebesar 90\% peserta mampu membuat kerajinan dari bahan akrilik melalui kegiatan pelatihan (Ratnawuri dan Farida, 2019). Salah satu yang dapat dikembangkan adalah melalui pelatihan keterampilan pembuatan kerajinan dari kain flanel layak jual. Membuat aksesoris ataupun aneka kerajinan biasanya lebih banyak dilakukan oleh kelompok remaja putra dan putri yang aktif dan kreatif. Kerajinan dari bahan kain flanel yang mudah dibentuk dan memiliki tampilan yang menarik salah satunya dengan membuat hiasan dinding (wall decoration) dari kain flanel. Flanel atau felt adalah jenis kain yang dibuat dari serat wol tanpa ditenun, dibuat dengan proses pemanasan dan penguapan sehingga menghasilkan kain dengan beragam tekstur dan jenis (tergantung bahan pembuatnya). Flanel adalah jenis kain tertua lebih tua dari kain tenun dan rajut. (Retguntari, 2007). Melalui pelatihan pembuatan wall decoration dari kain flanel bagi remaja panti asuhan Tuma'ninah Yasin diharapkan dapat menumbuhkan dan mengembangkan jiwa kewirausahaan sehingga dapat menjadi bekal wira usaha mandiri.

Kelebihan kain flanel adalah mudah dijumpai di pasaran dan dengan harga yang relatif terjangkau. Kain ini memiliki ketebalan dan tekstur yang beragam (Linawati, 2010). Dengan tampilan yang warna-warni membuat kain flanel lebih menarik untuk dibuat kreasi produk kerajinan yang bernilai jual. Kelebihan lain dari kain flanel adalah harganya yang terjangkau sehingga memungkinkan berwirausaha dengan modal yang tidak terlalu besar. Melalui pelatihan pembuatan wall decoration kain flanel ini diharapkan dapat menjadi bekal wira usaha mandiri bagi remaja panti 
asuhan Tuma'ninah Yasin Kota Metro.

Tujuan kegiatan ini adalah untuk memberikan pelatihan pembuatan wall decoration kain flanel sebagai bekal wirausaha mandiri remaja panti asuhan Tuma'ninah Yasin.

\section{METODOLOGI}

Kegiatan ini dilakukan di Panti Asuhan Tuma'nina Yasin Kota Metro. Alasan dipilih tempat ini sebagai sasaran kegiatan adalah karena banyak remaja yang belum memiliki bekal untuk berwirausaha mandiri. Melalui kegiatan ini diharapkan para remaja memiliki inisiatif dan pengalaman dalam membuat kerajinan yang lain.

Kegiatan pelatihan pembuatan wall decoration kain flanel digunakan beberapa metode sebagai berikut.

1. Metode demonstrasi, yaitu digunakan oleh pengabdi untuk memperagakan langkah-langkah pembuatan wall decoration kain flanel kepada peserta pelatihan yaitu remaja panti Asuhan Tuma'ninah Yasin Kota Metro.

2. Metode tanya jawab, yaitu digunakan untuk mengajukan dan menjawab pertanyaan dari peserta pelatihan kepada pemateri/tim pengabdi apabila terdapat hal-hal yang belum paham pada saat kegiatan pelatihan berlangsung. Selain itu juga untuk mengukur pemahaman dari peserta pelatihan setelah tim pengabdi menyampaikan materi pada metode demonstrasi.

3. Metode diskusi, yaitu peserta pelatihan dan tim pengabdi dibantu oleh mahasiswa melakukan dialog mengenai cara pembuatan wall decoration dari kain flanel. Dalam diskusi ini juga sering terjadi masukan atau ide-ide baik dari peserta maupun tim pengabdi mengenai berbagai kerajinan lain yang dapat dibuat dari kain flanel.

4. Metode praktek, yaitu digunakan ketika peserta pelatihan mendapatkan melakukan kegiatan langsung dalam membuat wall decoration kain flanel.

\section{HASIL DAN PEMBAHASAN}

Hasil yang diperoleh setelah melakukan kegiatan pelatihan pembuatan wall decoration kain flanel. Berikut ini contoh produk wall decoration kain flanel pada Gambar 1.

Pelatihan pembuatan wall decoration kain flanel dilakukan di masjid panti asuhan Tuma'ninah Yasin Kota Metro. Pemateri dalam kegiatan ini dilakukan oleh tim pengabdi yaitu Nurul Farida, M.Pd, Lilian Mega Puri, M.Pd., dan Triani Ratnawuri, M.Pd. Selanjutnya tim pengabdi dibantu oleh lima orang mahasiswa yaitu Eka Apriliyanti, Dwi Margirahayu, Eka Rachmawati, Cialing Susanti, dan Nawal Sartika Sari. Kegiatan ini dihadiri oleh 15 peserta Workshop pelatihan pembuatan wall decoration kain flanel dilaksanakan pada hari Senin tanggal 22 Juni 2020.

Susunan acara kegiatan pelatihan pembuatan wall decoration kain flanel sebagai berikut: a) pembukaan, b) Sambutan Pengurus Panti Asuhan Tuma'ninah Yasin 
Metro, c) Praktek pembuatan wall decoration dari kain flannel, d) Penutup dengan foto bersama antara mitra yaitu remaja panti asuhan Tuma'ninah Yasin Metro dengan dan tim pengabdi dari Universitas Muhammadiyah Metro.

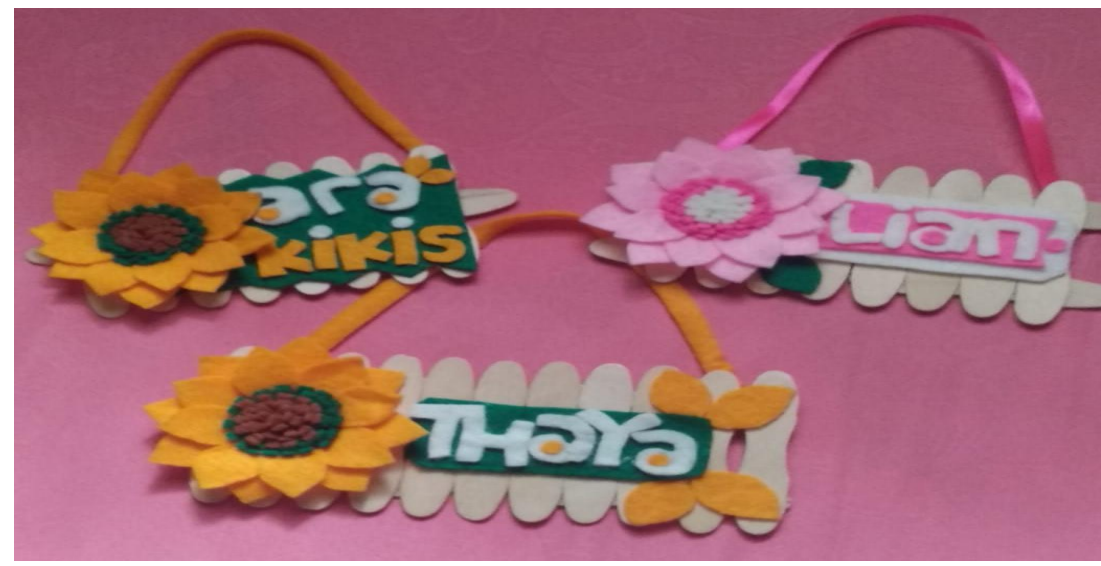

Gambar 1. Contoh Produk Wall Decoration Kain Flanel

Kegiatan pelatihan pembuatan wall decoration dilakukan dengan tahapan sebagai berikut.

a. Pengenalan alat dan bahan.

Alat dan bahan yang digunakan adalah:

1. Kain flannel berbagai warna

2. Gunting

3. Penggaris

4. Pena

5. Lem tembak

6. Stik Es krim

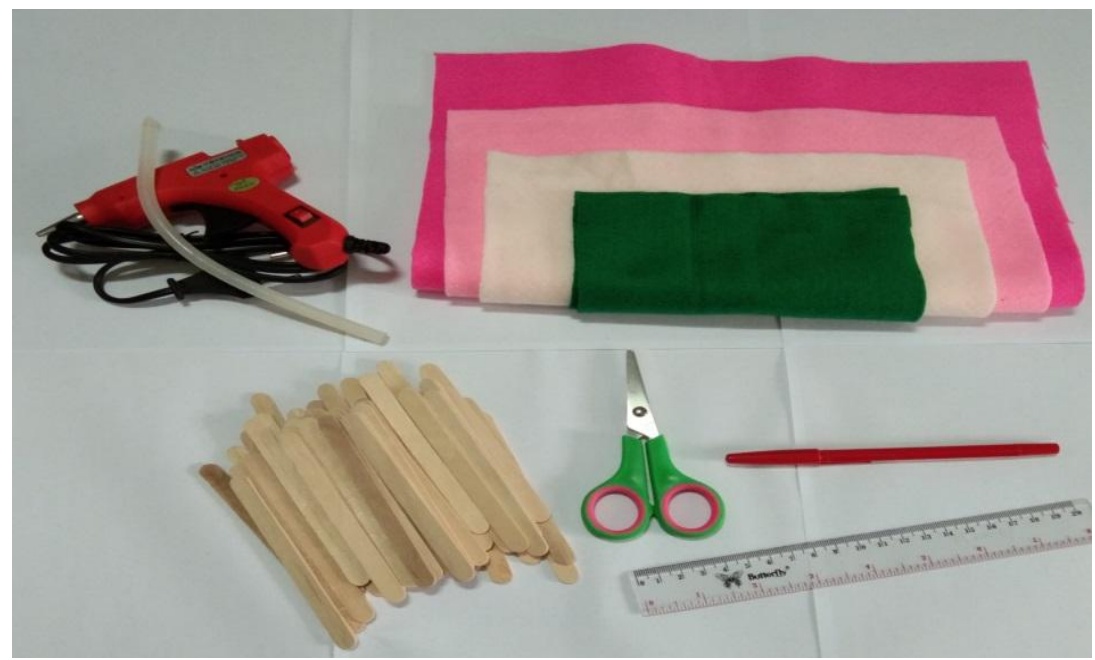

Gambar 2. Alat dan Bahan Membuat Wall Decoration Bunga Flanel 
b. Mendemonstrasikan cara membuat wall decoration bentuk bunga kepada peserta pelatihan yaitu remaja panti asuhan panti asuhan Tuma'ninah Yasin.

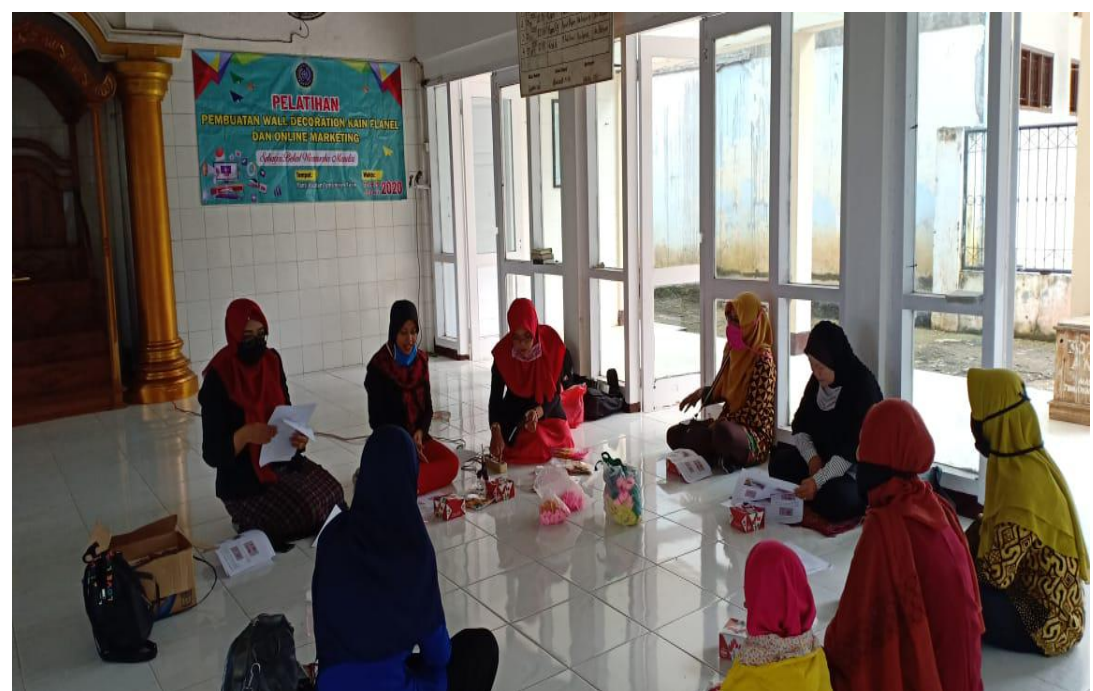

Gambar 3. Tim Mendemonstrasikan Pembuatan Wall Decoration Kain Flanel

c. Praktek membuat wall decoration bunga kain flannel. Untuk membuat satu bunga flanel dilakukan dengan cara sebagai berikut.

1. Buatlah ukuran pada kain flanel, dengan menggunakan bantuan penggaris dan pena yaitu ukuran $3 \times 3,24 \times 2,28 \times 2$, lalu potong masing-masing ukuran dengan gunting. Untuk ukuran $3 \times 3$ jumlahnya minimal 32 lembar.

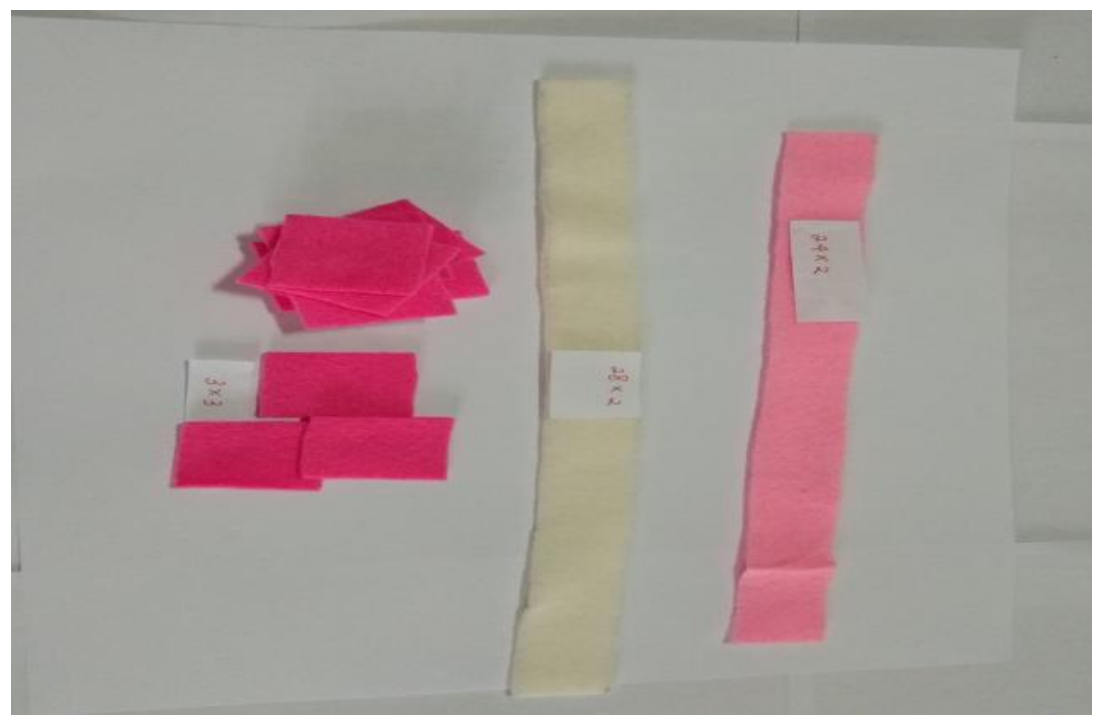

Gambar 4. Ukuran Pembuatan 1 Bunga 
2. Gunting kain flannel berukuran persegi $3 \times 3$ gunting kedua sisi berseberangan menjadi bentuk kelopak bunga, seperti pada gambar seperti gambar di bawah ini.

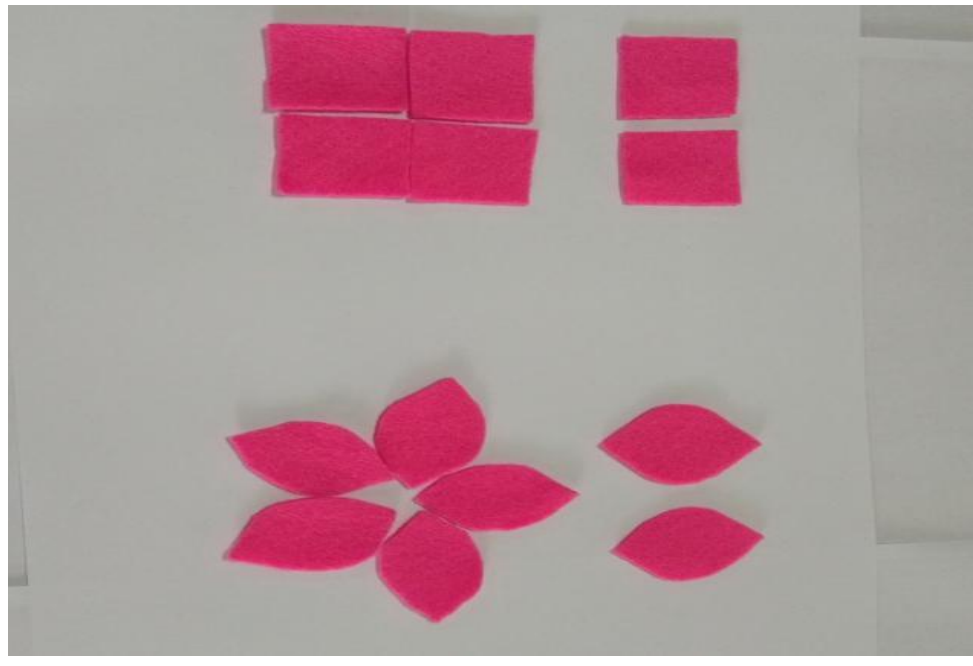

Gambar 5. Potongan Kelopak Bunga

3. Untuk potongan kain flannel berukuran panjang, gunting kecil-kecil berukuran $0,5 \mathrm{~cm}$ bagian satu sisinya kira-kira setengah dari lebar kain. Seperti pada gambar di bawah ini.

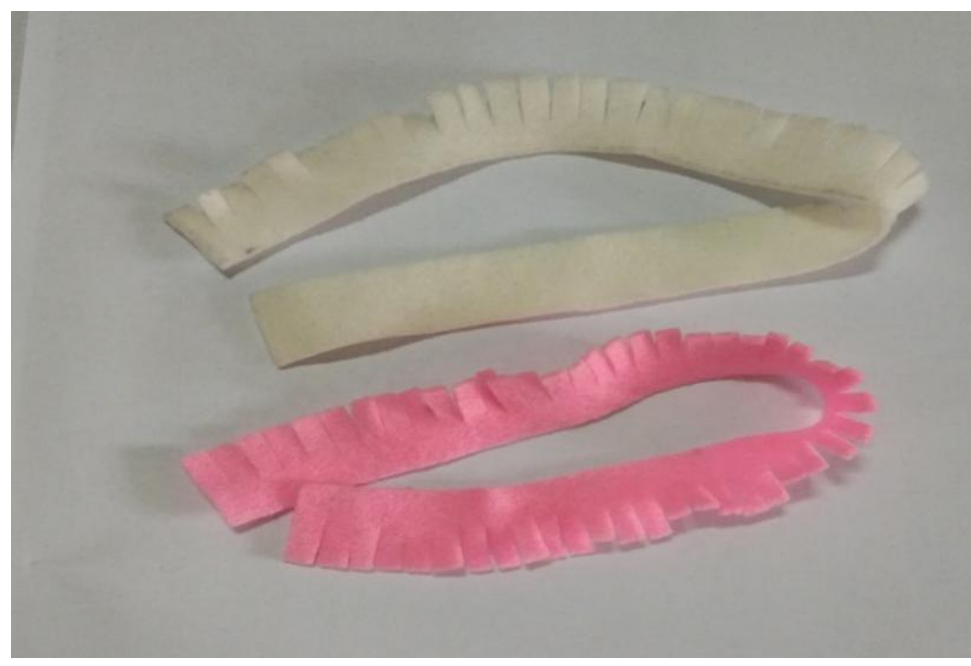

Gambar 6. Sari Bunga

4. Gulung kain flannel panjang berukuran $28 \times 2$ dengan menggunakan lem tembak. Hasil yang akan didapatkan seperti pada Gambar 7. 


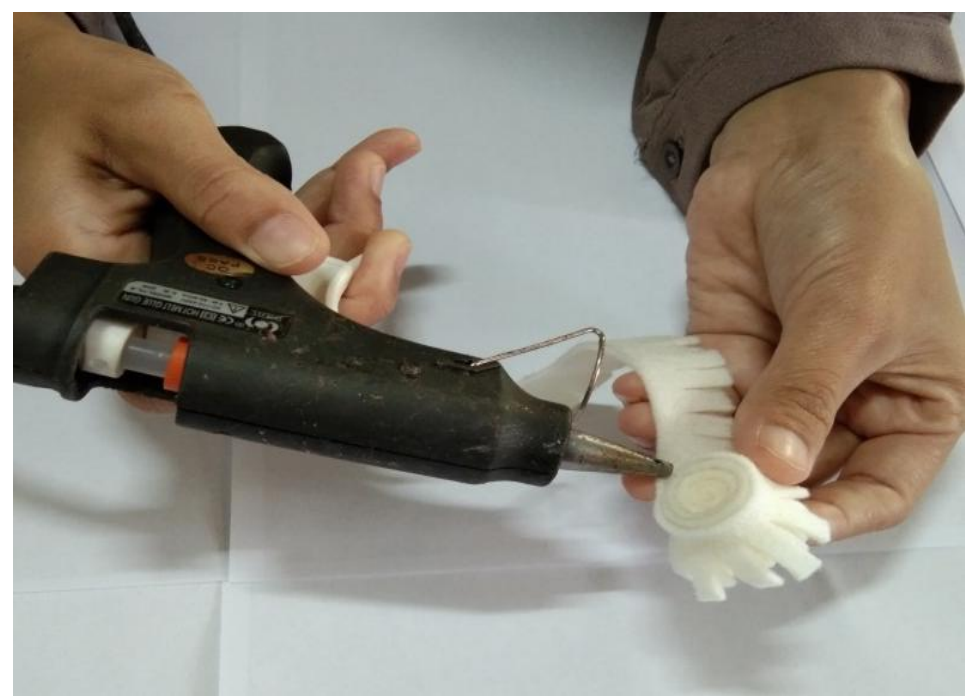

Gambar 7. Gulungan Sari Bunga Ukuran 28x2

5. Rekatkan gulungan kain yang telah di gulung tadi yang berbentuk seperti sari bunga (silinder) ukuran 28x2 rekatkan dan gulung pada kain berukuran $24 \times 2$ dengan menggunakan lem tembak seperti pada Gambar 8.
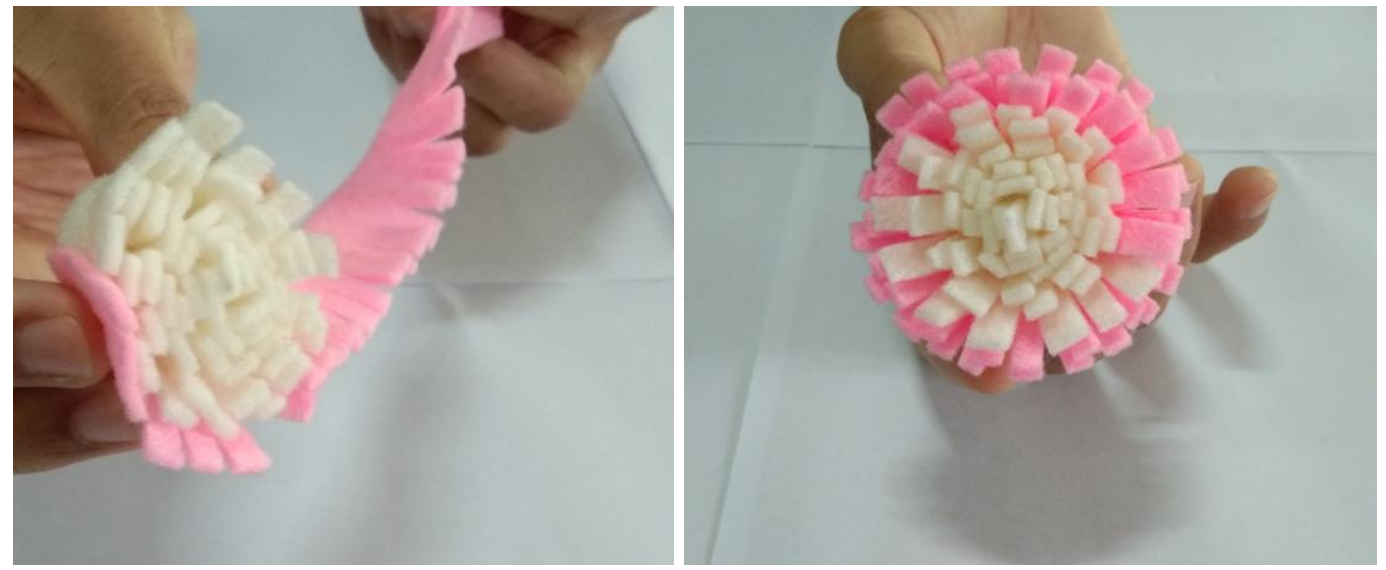

Gambar 8. Gulungan Sari Bunga Ukuran 28x2 yang Ditempel Pada Ukuran 24x2

6. Rekatkan potongan kain berbentuk kelopak bunga secara melingkar dan teratur pada gulungan sari bunga yang telah disiapkan satu persatu menggunakan lem tembak. Hasilnya seperti pada Gambar 9. 

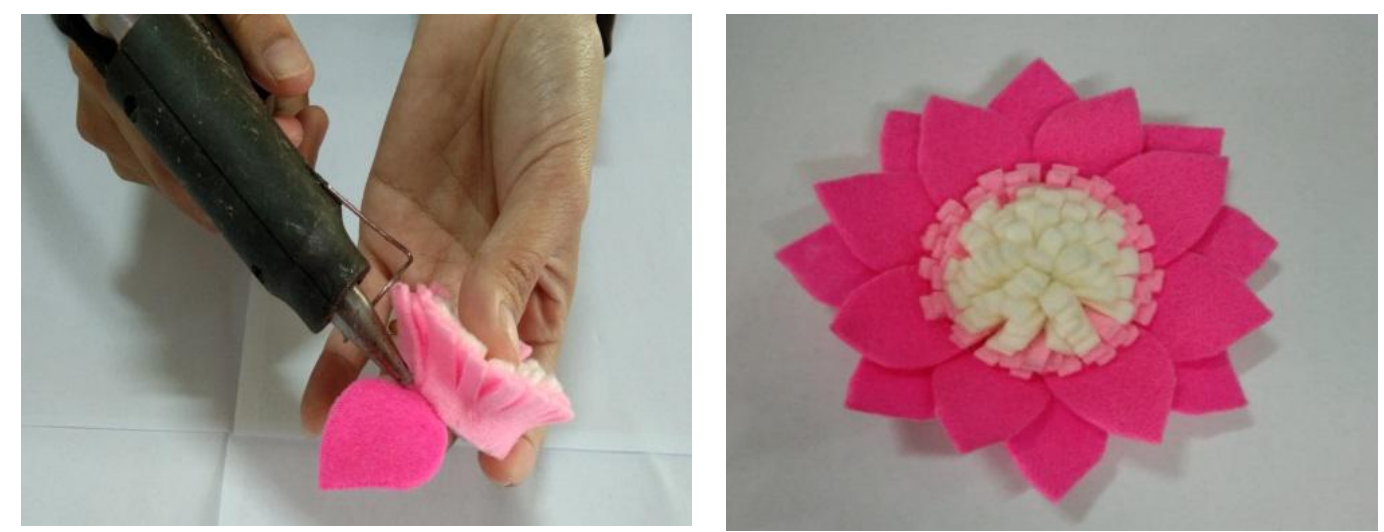

Gambar 9. Bentuk Bunga yang Sudah Jadi

7. Untuk membuat bingkai bunga siapkan 22 stik es krim dan susun menggunakan lem tembak. Selanjutnya tempel bunga yang sudah jadi menjadi hiasan dinding yang diinginkan. Bentuk wall decoration yang sudah jadi dapat seperti gambar di bawah ini.

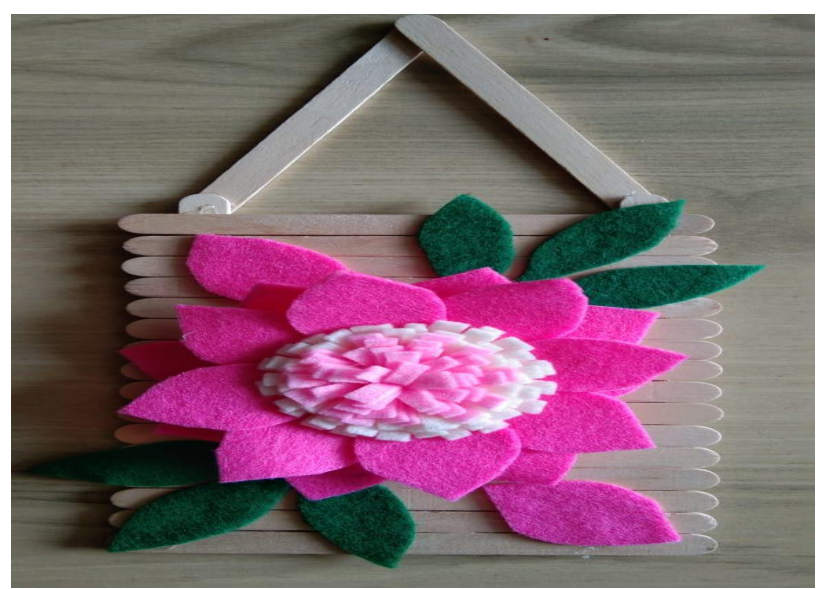

Gambar 10. Wall Decoration Kain Flanel yang Sudah Jadi

d. Tahap terakhir dari kegiatan pelatihan adalah foto bersama antara anggota mitra remaja Panti Asuhan Tuma'ninah yasin Kota Metro dengan Tim pengabdi dari Universitas Muhammadiyah Metro dengan memamerkan hasil karya dari wall decoration kain flanel.

Selama prektek berlangsung terjadi diskusi dan tanya jawab antara tim pengabdi dengan peserta pelatihan. Diskusi ini mengenai kegunaan dan ide kreatif yang bisa dibuat dari kain flanel yang ternyata banyak dijadikan kerajinan yang lain tidak hanya wall decoration saja tetapi juga bisa dikreasikan menjadi bentuk tali gorden, bros, bunga, dan masih banyak yang lainnya. Para remaja Panti asuhan Tuma'ninah Yasin Kota Metro tampak antusias dan tertarik dalam membuat berbagai wall decoration kain flannel. Kegiatan pelatihan yang dilakukan juga dapat menjadi bekal wirausaha mandiri 
bagi peserta pelatihan/mitra. Dari 15 peserta pelatihan 93\% peserta mampu membuat wall decoration dari kain flanel. Melalui kegiatan pelatihan dapat menumbuhkan jiwa kewirausahaan peserta pelatihan (Sukirman, 2017). Melalui kegiatan pelatihan, peserta pelatihan memiliki peningkatan pengetahuan (Sarfika, dkk; 2020. Selain itu berdasarkan hasil kegiatan yang dilakukan (Asful, dkk; 2016) bahwa 70\% Tercapainya target keterampilan peserta terkait materi kegiatan ini melalui pelatihan.

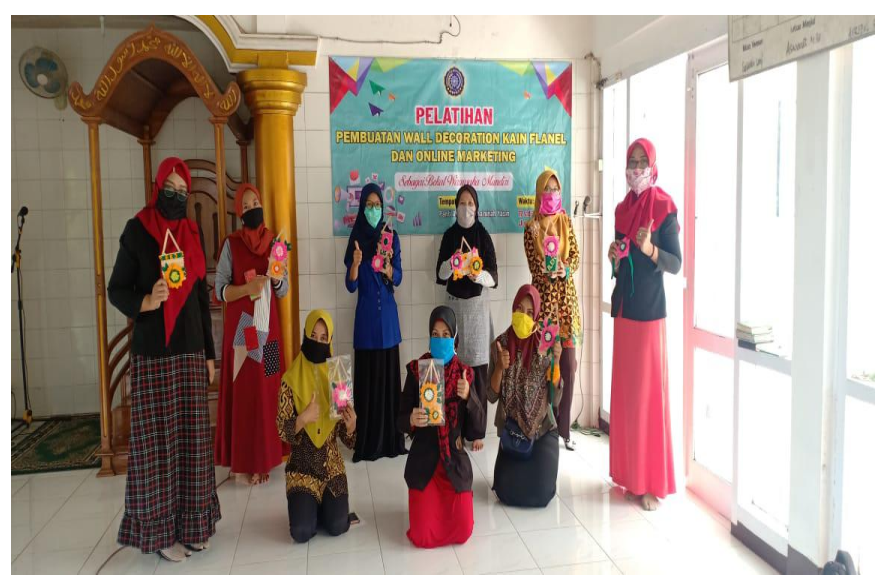

Gambar 11. Foto Bersama dengan Memamerkan Wall Decoration Kain Flanel yang Telah Dibuat

\section{KESIMPULAN DAN SARAN}

Remaja panti asuhan Tuma'ninah Yasin Kota Metro mampu meningkatkan pengetahuan dan kemampuan mengenai pembuatan wall decoration. Dari 15 peserta pelatihan 93\% peserta mampu membuat wall decoration kain flanel. Mitra juga memperoleh bahan produk dari kain flanel untuk membuat wall decoration atau juga dapat digunakan untuk membuat berbagai macam kerajinan dari kain flanel. Dengan pengetahuan dan kemampuan yang telah diperoleh, peserta pelatihan/mitra dapat mengembangkan pembuatan berbagai macam kerajinan/produk handmade dari kain flanel sehingga mampu mengembangkan dan menjadi bekal wirausaha mandiri.

\section{UCAPAN TERIMAKASIH}

Tim mengucapkan terima kasih kepada Lembaga Pengabdian Pada Masyarakat (LPPM) Universitas Muhammadiyah Metro yang telah mendanai kegiatan pengabdian ini sehingga terlaksana dengan baik. Selain itu, pengabdi juga mengucapkan terima kasih kepada pihak pihak panti asuhan Tuma'ninah Yasin Kota Metro yang telah memberikan kesempatan untuk melaksanakan kegiatan. 


\section{DAFTAR PUSTAKA}

Asful, F. 2016. Pelatihan pemberdayaan kelembagaan petani menuju pengembangan kewirausahaan sosial bagi gapoktan Se Kabupaten Solok Selatan. Warta Pengabdian Andalas. Jurnal Ilmiah dan Penerapan Ipteks. 23 (1).

Firdani, N.N.A., Suryadi, A, dan Saripah, L. 2017. Kemandirian berwirausaha pemuda produktif melalui program pendidikan kecakapan hidup. Jurnal Pendidikan Luar Sekolah. 1 (1): 63-76.

Hendrawan, Y dan Wahyuni, S. 2016. Pengaruh Pelatihan pengembangan dan motivasi terhadap peningkatan kinerja pegawai dengan mediasi komitmen organisasi. Jurnal Bisnis dan Manajemen. 16 (1): 89-104.

Linawati. 2010. Replika Kue Flanel.Tiara Aksa, Surabaya. Ratnawuri, T dan Farida, N. 2019. Pengembangan entrepreneurship melalui pelatihan pembuatan kerajinan akrilik. Jurnal Masyarakat Mandiri. 3 (2): 156-163.

Retguntari, D. 2007. Aneka Kreasi Flanel, Praktis, Fungsional, dan Bernilai Jual. Qultum Media, Jakarta.

Sarfika, R. 2020. Pelatihan komunikasi terapeutik guna meningkatkan pengetahuan perawat dalam caring. Jurnal Hilirasi IPTEKS. 3 (1): 79-87.

Sukirman. 2017. Jiwa kewirausahaan dan nilai kewirausahaan meningkatkan kemandirian usaha melalui perilaku kewirausahaan. Jurnal Ekonomi dan Bisnis. 20 (1): 113-132.

Sulaefi. 2017. Pengaruh pelatihan dan pengembangan terhadap disiplin kerja dan kinerja karyawan. Jurnal Manajemen dan Kewirausahaan. 5 (1): 8-21.

Wibowo, M. 2011. Pembelajaran kewirausahaan dan minat wirausaha lulusan SMK. Eksplansi, 6 (2). 109-122. 